\title{
Association between Nutritional Status and Positive Childhood Disability Screening Using the Ten Questions Plus Tool in Sarlahi, Nepal
}

\author{
L. Wu', J. Katz', L.C. Mullany', E. Haytmanek², S.K. Khatry³, G.L. Darmstadt',4, \\ K.P. West, Jr.', S.C. LeClerq, ${ }^{1,3}$, and J.M. Tielsch'
}

'Department of International Health, Bloomberg School of Public Health, Johns Hopkins University, Baltimore, MD, USA, ${ }^{2}$ Institute of Medicine, Washington, DC, USA, ${ }^{3}$ Nepal Nutrition Intervention Project-Sarlahi, Kathmandu, Nepal, and ${ }^{4}$ Integrated Health Solutions Development, Global Health Programme, Bill \& Melinda Gates Foundation, Seattle, Washington, DC, USA

\begin{abstract}
The study was conducted to examine the association between the indicators of malnutrition and disability of children as reported by caregivers. The Ten Questions Plus questionnaire was administered to caregivers of 1,902 children aged 1-9 years, during August 2007-March 2008, in rural Nepal. Height and weight of children were also measured. The main outcome was a positive response to one or more questions. In total, 514 $(27 \%)$ children had a positive response to at least one question. Moderate stunting [odds ratio $(\mathrm{OR})=1.47$, 95\% confidence interval (CI) 1.02-2.12) and severe (OR=2.39, 95\% CI 1.60-3.57) stunting were independently associated with reported delay in sitting, standing, or walking. Severe stunting was also associated with report of delayed learning compared to other children of similar age (OR=2.01, 95\% CI 1.27-3.20). Parental report of disability was quite prevalent in this setting, with over a quarter of the sample screening positive. Chronic malnutrition may be associated with delayed motor and mental development.
\end{abstract}

Kew words: Child; Child development; Child nutrition; Cognitive development; Disability; Stunting; Nepal

\section{INTRODUCTION}

Disability is defined by the United Nations (UN) as "long-term physical, mental, intellectual or sensory impairments which, in interaction with various barriers, may hinder [a person's] full and effective participation in society on an equal basis with others" (1). With the adoption of the UN Convention on the Rights of Persons with Disabilities, the United Nations Children's Fund (UNICEF) has made the inclusion and development of children with disabilities a priority issue, and the World Health Organization (WHO) estimates that over 200 million children worldwide are at risk for not meeting their developmental potential (2). Few data are

Correspondence and reprint requests should be addressed to:

Dr. Joanne Katz

Professor and Associate Chair

Department of International Health

Bloomberg School of Public Health

Johns Hopkins University

615 North Wolfe Street, W5009

Baltimore, MD 21205-2103

USA

Email: jkatz@jhsph.edu

Fax: 410-955-2029 available, however, on the prevalence of and risk factors for children with disabilities in developing countries.

The Ten Questions (TQ) screen was developed in 1984 as a tool for screening children aged 2-9 years in resource-poor settings to identify disabilities and to refer screen-positive children for further clinical evaluation and intervention (3). It focuses on questions about general functional abilities and milestones rather than culture-specific skills (4). A child is considered screen-positive if his or her parent responds 'yes' to one or more of the 10 questions. The TQ tool, evaluated and validated in over 20 countries to date, is highly sensitive (5-7). The tool has a low positive predictive value for serious disability but these 'false-positive' children are often found to have either mild disability or a health condition requiring treatment (5). Thus, the TQ tool is best used as a screen for identifying children with developmental delays or who are at an increased risk of disability (4).

The UNICEF currently recommends the incorporation of the TQ tool into its Multiple Indicator Cluster Survey (MICS) programme to address the gap in knowledge about childhood disabilities in develop- 
ing countries. The most recent MICS in 2005-2006 included results of TQ screening of over 190,000 children in 18 developing countries. Nutritional factors, such as not being breastfed, no receipt of vitamin A supplementation, wasting, and stunting, were significantly associated with screening positive for disability (8). In their data, anthropometric measures were only available for children aged less than five years, and little is known about the association of poor nutritional status with loss of developmental potential in children aged over five years $(2,4,8)$. This age-group is important to measure because child development is related to school attendance, which then affects earning potential later in life (2).

In the present study, we used data from rural southern Nepal to estimate the prevalence of parental report of various types of disabilities in children aged 1-9 years and their associations with nutritional status using a modified TQ- the Ten Questions Plus (TQP). While the TQ tool has been used in Bangladesh, Pakistan, and India, it has not been used in Nepal $(5,9)$. Additionally, most prior evaluation of TQ has been done in a mix of urban and rural areas, and our community-based sample comes from an entirely rural area. The additional eleventh question (the 'Plus') has not been previously evaluated in the published literature. Lastly, while the MICS looked at the overall prevalence of screen-positivity, we also examined the association of nutritional indicators with individual questions on the screen. This can provide additional information on specific types of disability and the burden in this rural South Asian population, adding to the body of knowledge on where to target interventions in similar settings to prevent or treat childhood disability (4).

\section{MATERIALS AND METHODS}

\section{Ten Questions Plus questionnaire}

The TQ tool, with one question added to the original 10, was developed and tested by the Bangladesh Protibondhi Foundation as part of the International Pilot Study of Severe Childhood Disability (10). The additional eleventh question assesses behavioural problems, e.g. frequent tantrums, aggressive behaviour, or difficulty relating to people, and the resulting screening tool is referred to as the TQ Plus (TQP) questionnaire (questions in Table 1).

\section{Study population and data collection}

The TQP was administered to a sample of children who had previously participated in the Nepal Nutrition Intervention Project-Sarlahi (NNIPS-4) study, which has been described in detail elsewhere
$(11,12)$. Given the prevalence of a positive screen and of stunting in this population, the sample-size was adequate to detect an odds ratio of 1.4 with power of $90 \%$. Briefly, the NNIPS-4 was a community-based, cluster-randomized $2 \times 2$ factorial trial of the impact of daily iron and/or zinc supplementation on mortality, morbidity, and physical growth. Children were cluster-randomized to receive one of four supplements (placebo, iron/folic acid, zinc, or zinc and iron/folic acid) daily from the time of enrollment (1 month) to discharge (36 months). The trial was conducted in Sarlahi district during October 2001-January 2006 among 426 clusters (sectors) across 30 Village Development Committees (VDCs), a government-defined administrative unit.

The sample for the TQP screening and nutrition study included children residing in one (Ishwarpur) of the 30 VDCs and who had previously participated in the NNIPS-4 trial. The TQP screening was nested within a larger follow-up of anthropometric status among infants in the previous iron/zinc trial (13). The additional TQP data-collection component was begun after $30 \%$ of the larger study had been completed, and all eligible children not yet visited were included after the starting date. The instrument was translated from English into Nepali and then backtranslated by a different person to make sure that the English and Nepali versions were the same. There were seven interviewers, one of whom conducted $30 \%$ of the interviews, two conducted $18 \%$ each, and the remainder conducted $10 \%$, except for one who conducted $4 \%$ of the interviews. We do not have inter- and intra-reliability on these interviewers. The questionnaire was pretested in a population similar to this one but who were not participants in this follow-up trial. Once collection of data using the TQP started on 18 September 2007, anthropometric measures were taken at the same visit as the TQP administration. Data were collected through March 2008. Although this is not a random sample of NNIPS-4 participants, the children selected for interview represent a geographically-distributed population throughout Ishwarpur.

The standing height of the child was measured using a portable Harpenden stadiometer to the nearest $0.1 \mathrm{~cm}$. Weight was measured using the Seca $881 \mathrm{u}$ scale to the nearest $0.1 \mathrm{~kg}$. Mid-upper arm circumference (MUAC) was measured to the nearest 0.1 $\mathrm{cm}$ using an insertion tape at the midpoint of the upper left arm with the left sleeve of the child removed. The tape was loosened and repositioned in between each reading. Height, weight, and MUAC were measured three times each, and the median 


\begin{tabular}{|c|c|c|}
\hline Question & No.* & Yes $(\%)$ \\
\hline Child's mother & 1,322 & 69.5 \\
\hline Child's father & 102 & 5.4 \\
\hline Other relatives (grandparent, aunt/uncle, sibling, other) & 473 & 24.9 \\
\hline $\begin{array}{l}\text { Q1 Motor milestones } \\
\text { Compared with other children, did your child have any } \\
\text { serious delay in sitting, standing, or walking? }\end{array}$ & 196 & 10.3 \\
\hline $\begin{array}{l}\text { Q2 Vision } \\
\text { Compared with other children, does your child have } \\
\text { difficulty in seeing, either in daytime or night time? }\end{array}$ & 16 & 0.8 \\
\hline $\begin{array}{l}\text { Q3 Hearing } \\
\text { Does your child appear to have difficulty in hearing? }\end{array}$ & 43 & 2.3 \\
\hline $\begin{array}{l}\text { Q4 Understanding } \\
\text { When you tell your child to do something, does s/he have } \\
\text { problems in understanding what you are saying? }\end{array}$ & 37 & 2.0 \\
\hline $\begin{array}{l}\text { Q5 Movement } \\
\text { Does your child have difficulty in walking or moving his/ } \\
\text { her arms or does s/he have weakness and/or stiffness in } \\
\text { the arms or legs? }\end{array}$ & 31 & 1.6 \\
\hline $\begin{array}{l}\text { Q6 Fits/seizures } \\
\text { Does your child have fits/convulsions, become rigid or } \\
\text { lose consciousness? }\end{array}$ & 28 & 1.5 \\
\hline $\begin{array}{l}\text { Q7 Learning } \\
\text { Does the child have trouble in learning to do things like } \\
\text { other children of his/her age? }\end{array}$ & 182 & 9.6 \\
\hline $\begin{array}{l}\text { Q8 No speech } \\
\text { Is your child mute (not able to speak at all)? }\end{array}$ & 46 & 2.4 \\
\hline $\begin{array}{l}\text { Q9 Speech }{ }^{* *} \\
\text { Is your child's speech in any way different from normal? }\end{array}$ & 58 & 3.7 \\
\hline $\begin{array}{l}\text { Q10 Slowness** } \\
\text { Compared with other children of his/her age, does your } \\
\text { child appear in any way mentally slow, dull, or backward? }\end{array}$ & 45 & 2.9 \\
\hline $\begin{array}{l}\text { Q11 Behavioural problems** } \\
\text { Does your child show any behavioural problem, such as } \\
\text { frequent tantrums, aggressive behaviour, or difficulty in } \\
\text { relating to people? }\end{array}$ & 70 & 4.5 \\
\hline $\begin{array}{l}\text { Summary } \\
\text { Positive screening for disability ('yes' on any of the above } \\
\text { questions) }\end{array}$ & 514 & 27.0 \\
\hline
\end{tabular}

value of the three measures was used for analysis. Approximately 1 in 30 measurements were repeated to check inter- and intra-observer reliability.

\section{Statistics}

A summary indicator variable for positive disability screening was defined as a positive response on one or more of the screening questions (4). Weightfor-age z-score (WAZ), height-for-age z-score (HAZ), weight-for-height z-score (WHZ), and body mass index-for-age z-score (BMIZ) were calculated using the WHO 2005 reference population (14). The WHO 2000 reference population was used if the age-range of the child did not fall within the age range of the 2005 reference population. WAZ, HAZ, WHZ, and BMIZ were also dichotomized as $<-2$ standard deviation (SD) from the mean of the reference population and less than $-3 \mathrm{SD}$. Children with WHZ or BMIZ <-2 SD indicate moderate wasting/ acute malnutrition, and those with WHZ or BMIZ 
$<-3$ SD indicate severe wasting/acute malnutrition. Likewise, children with $\mathrm{HAZ}<-2$ SD indicate moderate stunting/chronic malnutrition, and those with $\mathrm{HAZ}<-3$ SD indicate severe stunting.

We modelled the adjusted odds of a positive response to any question as a function of each of the dichotomized z-scores (WAZ <-2 SD, HAZ <-2 SD, WHZ <-2 SD, BMIZ <-2 SD, WAZ <-3 SD, HAZ $<-3 \mathrm{SD}, \mathrm{WHZ}<-3 \mathrm{SD}$, and BMIZ <-3 SD). We also used multivariate regression to model the odds of a positive disability screen for a combination of anthropometric measures (keeping -2 SD variables and -3 SD variables together). BMIZ and WHZ were never modelled together in the logistic regressions because these are highly correlated and are both indicators of wasting. We also modelled the odds of a positive response to each of the 11 questions separately using the same procedure outlined above. In all the logistic regression models, we adjusted for the age and sex of the child, maternal literacy, household caste, ethnicity, iron and zinc supplementation group, and an asset ownership scale (an ordinal variable ranging from 0 to 10 from a composite score of 1 if 'yes', 0 if 'no' on ownership of latrines, cattle, goats, carts, bicycles, radios, electricity in the home, land, televisions, and presence of servants) (15).

We performed likelihood ratio tests to compare extended models to null models not adjusted for potential confounders. Interactions of age and sex with anthropometric measures were tested in logistic regression models. We examined the number of unique covariate patterns in the data and assessed goodness-of-fit of the model using Pearson's method because there were many non-unique covariate patterns. Last, we looked at model residuals, leverage, and influence to check model fit and assumptions. Data were analyzed using the Stata software (version 10) and the SAS software (version 9.2) $(16,17)$.

\section{Ethics}

Verbal informed consent was obtained from the primary caregiver of each child. The Ethical Review Board of the Nepal Health Research Council, Kathmandu, and the Institutional Review Board of the Johns Hopkins Bloomberg School of Public Health approved the study.

\section{RESULTS}

In total, 3,194 children from Ishwarpur in the original NNIPS-4 iron/zinc supplementation trial were eligible to receive the TQP screen (Fig.). Twentyeight children had died, 59 had moved, and one refused to participate. Of the remaining 3,106 children, the TQP was administered to a populationbased sample of 1,902. Of them, 1,728 (91\%) were weighed, 1,651 (87\%) had height, and 1,735 (91\%) had MUAC measured. Age and sex were available for all the 1,902 children.

The eligible children from Ishwarpur, who did not receive the TQP screen $(n=1,251)$, were comparable on all characteristics except that those who received the screen had a higher prevalence of wasting as measured by WHZ (38.2\% vs $29.9 \%)$ and BMIZ (31.4\% vs 21.5\%). The children who received the TQP came from families that owned less land (46.6\% vs 54.4\%, p<0.00001) and fewer bullock carts $(9.6 \%$ vs $16.0 \%, \mathrm{p}<0.00001)$ than those who did not receive the TQP.

The age of the TQP participants ranged from 1.4 to 8.9 years (mean 5.0 years); $51.4 \%$ were male (Table

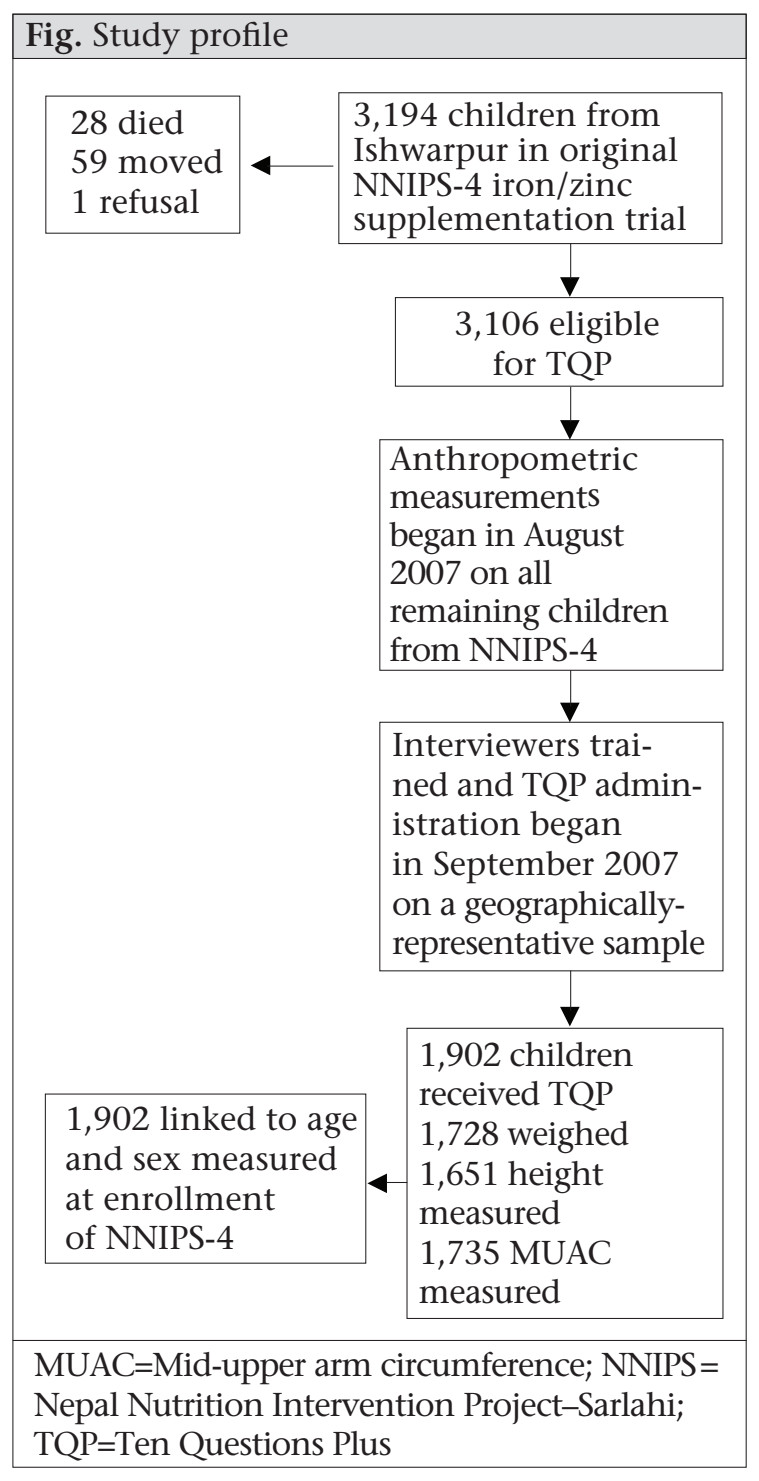


2). The prevalence of $\mathrm{WHZ}<-2$ and $<-3$ was $38.2 \%$ and $14.3 \%$ respectively. The prevalence of $\mathrm{HAZ}<-$ 2 and -3 was $49.5 \%$ and $17.1 \%$ respectively. The mean $\mathrm{BMI}$ was $14.0(\mathrm{SD}=1.4)$, and the mean MUAC was $14.6 \mathrm{~cm}(\mathrm{SD}=1.1)$. The majority of the children came from the Vaiysha (farmers, traders, craftsmen) caste $(58.2 \%)$; smaller proportions were from the Shudra (menial, servants, craftsmen) castes (13.6\%); and $21.1 \%$ were from Muslim families. Eighty-five percent belonged to the Madheshi ethnic group (native to Nepal and residing in the southern plains). About $20 \%$ of the mothers $(n=363)$ were literate. Less than $10 \%$ of the households owned a latrine $(n=160)$, servant $(n=83)$, or bullock cart $(n=183)$.

Of the respondents, $69.5 \%$ were mothers $(n=1,322)$, $5.4 \%$ were fathers $(n=102)$, or $25.1 \%$ were other relatives $(n=473)$. The proportion of positive responses (of 1,902) to each question (Table 1 ) ranged from $0.8 \%(\mathrm{n}=16)$ answering 'yes' to Question 2: vision problems to $10.3 \%(n=196)$ answering 'yes' to Question 1: motor milestone delay.

Overall, 514 (27\%) children screened positive for disability, with a 'yes' response to at least one

\begin{tabular}{|c|c|}
\hline Characteristics & $\begin{array}{l}\text { Mean } \pm \text { SD or } \\
\text { No. }(\%)\end{array}$ \\
\hline \multicolumn{2}{|l|}{ Child characteristics } \\
\hline Age (years) & $5.0 \pm 1.9$ \\
\hline Male & $978(51.4)$ \\
\hline Female & $924 \pm 48.6$ \\
\hline $\begin{array}{l}\text { Mid-upper arm } \\
\text { circumference }(\mathrm{cm})\end{array}$ & $14.6 \pm 1.1$ \\
\hline Body mass index $\left(\mathrm{kg} / \mathrm{m}^{2}\right)$ & $14.0 \pm 1.4$ \\
\hline $\mathrm{WAZ}^{*}$ & $-2.6 \pm 1.2$ \\
\hline WAZ $<-2$ SD & $1,136(69.7)$ \\
\hline WAZ $<-3 \mathrm{SD}$ & $541(33.2)$ \\
\hline $\mathrm{HAZ}^{*}$ & $-2.0 \pm 1.2$ \\
\hline $\mathrm{HAZ}<-2 \mathrm{SD}$ & $769(49.5)$ \\
\hline $\mathrm{HAZ}<-3 \mathrm{SD}$ & $265(17.1)$ \\
\hline $\mathrm{WHZ}^{*}$ & $-1.8 \pm 1.4$ \\
\hline WHZ $<-2$ SD & $571(38.2)$ \\
\hline $\mathrm{WHZ}<-3 \mathrm{SD}$ & $214(14.3)$ \\
\hline BMIZ* $^{*}$ & $-1.6 \pm 1.5$ \\
\hline $\mathrm{BMIZ}<-2 \mathrm{SD}$ & $487(31.4)$ \\
\hline $\mathrm{BMIZ}<-3 \mathrm{SD}$ & $206(13.3)$ \\
\hline \multicolumn{2}{|l|}{ Household characteristics } \\
\hline \multicolumn{2}{|l|}{ Caste } \\
\hline Brahmin & $87(4.6)$ \\
\hline Chhetri & $48(2.5)$ \\
\hline Vaiysha & $1,105(58.2)$ \\
\hline Shudra & $258(13.6)$ \\
\hline
\end{tabular}

\begin{tabular}{|c|c|}
\hline \multicolumn{2}{|l|}{ Table. 2-Contd. } \\
\hline Muslim & $400(21.1)$ \\
\hline \multicolumn{2}{|l|}{ Ethnicity } \\
\hline Pahadi & $277(14.7)$ \\
\hline Madheshi & $1,607(85.3)$ \\
\hline Mother literate & 363 (19.9) \\
\hline Father literate & $1,037(55.1)$ \\
\hline Latrine in house & $160(8.4)$ \\
\hline Servant(s) in house & $83(4.4)$ \\
\hline Cattle & $994(52.4)$ \\
\hline Goat(s) & 758 (39.9) \\
\hline Land ownership & $873(46.6)$ \\
\hline Bullock cart(s) & $183(9.6)$ \\
\hline Bicycle(s) & $954(50.3)$ \\
\hline Radio(s) & $440(23.1)$ \\
\hline Electricity in home & $536(28.2)$ \\
\hline Television & $388(20.5)$ \\
\hline \multicolumn{2}{|c|}{$\begin{array}{l}\text { *Combination of WHO } 2000 \text { and } 2005 \text { reference } \\
\text { populations, each of which covers different age } \\
\text { range (14); } 2000 \text { reference population was used } \\
\text { only if not in age range for } 2005 \text { reference popu- } \\
\text { lation; Missing values: Weight: } 174 \text {, Height: } 251 \text {, } \\
\text { MUAC: } 167 \text {, BMI: } 253 \text {, WAZ: } 273 \text {, HAZ: } 349 \text {, } \\
\text { WHZ: } 401 \text {, BMIZ: 351, Caste: } 4 \text {, Ethnicity: } 18 \text {, Mat- } \\
\text { ernal literacy: 73, Paternal literacy: } 21 \text {, Latrine: } 5 \text {, } \\
\text { Servants: 3, Cattle: } 3 \text {, Goats: 3, Land: } 29 \text {, Carts: } \\
\text { 4, Bicycles: 5, Radios: 4, Electricity: } 3 \text {, Televi- } \\
\text { sions:8; BMIZ=BMI-for-age z-score; HAZ=He- } \\
\text { ight-for-age z-score; MUAC=Mid-upper arm } \\
\text { circumference; SD=Standard deviation from } \\
\text { the mean; WAZ=Weight-for-age z-score; WHO= } \\
\text { WorldHealth Organization; WHZ=Weight-for- } \\
\text { height z-score }\end{array}$} \\
\hline
\end{tabular}

question. Of these positive responses, 339 (64.4\%) screened positive based on two questions (Question 1: motor milestones and Question 7: learning). Severe stunting was marginally associated with an increased adjusted odds of screening positive (OR=1.33, 95\% CI 0.98-1.82).

Sex and continuous age (years) were independently significantly associated with positive TQP screening (OR female $=0.77$, 95\% CI 0.65-0.97; OR age $=0.82$, 95\% CI 0.78-0.87). For individual questions, we examined the association with nutritional indicators for those questions where $3 \%$ or more of the respondents answered positively (Table 3 ). The prevalence of a positive TQP screen was $31.2 \%$ among the severely-stunted children and $24.3 \%$ among the severely-underweight children.

Moderate stunting (OR=1.47, 95\% CI 1.02-2.12) and severe stunting (OR=2.39, 95\% CI 1.60-3.57) were each associated with increased adjusted odds of a positive response to Question 1: motor mile- 


\begin{tabular}{|c|c|c|c|c|c|c|c|c|}
\hline \multirow{3}{*}{$\begin{array}{l}\text { Outcome } \\
\text { severity } \\
\text { of mal- } \\
\text { nutrition }\end{array}$} & \multicolumn{4}{|c|}{ Wasting $\ddagger$} & \multicolumn{4}{|c|}{ Stunting } \\
\hline & \multicolumn{2}{|c|}{ Crude } & \multicolumn{2}{|c|}{ Adjusted ${ }^{*}$} & \multicolumn{2}{|c|}{ Crude } & \multicolumn{2}{|c|}{ Adjusted $^{\star \star}$} \\
\hline & $\begin{array}{c}\text { OR } \\
(95 \% \mathrm{CI})\end{array}$ & $\begin{array}{c}\mathrm{p} \\
\text { value }\end{array}$ & $\begin{array}{c}\text { OR } \\
(95 \% \mathrm{CI})\end{array}$ & $\begin{array}{c}\mathrm{p} \\
\text { value }\end{array}$ & $\begin{array}{c}\text { OR } \\
(95 \% \mathrm{CI})\end{array}$ & $\underset{\text { value }}{\mathrm{p}}$ & $\begin{array}{c}\text { OR } \\
(95 \% \mathrm{CI})\end{array}$ & $\underset{\text { value }}{\mathrm{p}}$ \\
\hline \multicolumn{9}{|l|}{$\begin{array}{l}\text { Positive } \\
\text { screen }\end{array}$} \\
\hline $\begin{array}{l}\text { Mode- } \\
\text { rate }\end{array}$ & $\begin{array}{c}0.94 \\
(0.74-1.19)\end{array}$ & 0.60 & $\begin{array}{c}0.96 \\
(0.75-1.24)\end{array}$ & 0.72 & $\begin{array}{c}1.14 \\
(0.90-1.43)\end{array}$ & 0.27 & $\begin{array}{c}1.04 \\
(0.81-1.34)\end{array}$ & 0.76 \\
\hline Severe ${ }^{\dagger}$ & $\begin{array}{c}0.86 \\
(0.62-1.21)\end{array}$ & 0.39 & $\begin{array}{c}0.94 \\
(0.66-1.35)\end{array}$ & 0.74 & $\begin{array}{c}1.51 \\
(1.13-2.00)\end{array}$ & 0.005 & $\begin{array}{c}1.33 \\
(0.98-1.82)\end{array}$ & 0.07 \\
\hline \multicolumn{9}{|c|}{$\begin{array}{l}\text { Q1: Motor } \\
\text { milestones§ }\end{array}$} \\
\hline $\begin{array}{l}\text { Mode- } \\
\text { rate }\end{array}$ & $\begin{array}{c}1.17 \\
(0.84-1.64)\end{array}$ & 0.34 & $\begin{array}{c}1.17 \\
(0.82-1.66)\end{array}$ & 0.39 & $\begin{array}{c}1.55 \\
(1.11-2.16)\end{array}$ & 0.01 & $\begin{array}{c}1.47 \\
(1.02-2.12)\end{array}$ & 0.04 \\
\hline Severe & $\begin{array}{c}1.29 \\
(0.82-2.01)\end{array}$ & 0.27 & $\begin{array}{c}1.41 \\
(0.88-2.25)\end{array}$ & 0.15 & $\begin{array}{c}2.28 \\
(1.58-3.29)\end{array}$ & $<0.0001$ & $\begin{array}{c}2.39 \\
(1.60-3.57)\end{array}$ & $<0.0001$ \\
\hline \multicolumn{9}{|c|}{ Q7: Learning§ } \\
\hline $\begin{array}{l}\text { Mode- } \\
\text { rate }\end{array}$ & $\begin{array}{c}0.83 \\
(0.57-1.21)\end{array}$ & 0.33 & $\begin{array}{c}0.83 \\
(0.54-1.27)\end{array}$ & 0.38 & $\begin{array}{c}1.75 \\
(1.22-2.52)\end{array}$ & 0.003 & $\begin{array}{c}1.50 \\
(0.96-2.34)\end{array}$ & 0.07 \\
\hline Severe & $\begin{array}{c}0.62 \\
(0.34-1.13)\end{array}$ & 0.12 & $\begin{array}{c}0.81 \\
(0.41-1.60)\end{array}$ & 0.54 & $\begin{array}{c}2.84 \\
(1.94-4.15)\end{array}$ & $<0.0001$ & $\begin{array}{c}2.01 \\
(1.27-3.20)\end{array}$ & 0.003 \\
\hline \multicolumn{9}{|c|}{ Q9: Speech§ } \\
\hline $\begin{array}{l}\text { Mode- } \\
\text { rate }\end{array}$ & $\begin{array}{c}0.84 \\
(0.45-1.56)\end{array}$ & 0.58 & $\begin{array}{c}0.75 \\
(0.39-1.44)\end{array}$ & 0.38 & $\begin{array}{c}0.81 \\
(0.45-1.46)\end{array}$ & 0.48 & $\begin{array}{c}0.75 \\
(0.39-1.44)\end{array}$ & 0.58 \\
\hline Severe & $\begin{array}{c}1.38 \\
(0.65-2.90)\end{array}$ & 0.40 & $\begin{array}{c}1.25 \\
(0.56-2.78)\end{array}$ & 0.59 & $\begin{array}{c}0.52 \\
(0.18-1.46)\end{array}$ & 0.21 & $\begin{array}{c}0.48 \\
(0.17-1.39)\end{array}$ & 0.18 \\
\hline \multicolumn{9}{|c|}{$\begin{array}{l}\text { Q11: Behavioural } \\
\text { problems§ }\end{array}$} \\
\hline $\begin{array}{l}\text { Mode- } \\
\text { rate }\end{array}$ & $\begin{array}{c}0.90 \\
(0.52-1.55)\end{array}$ & 0.70 & $\begin{array}{c}0.93 \\
(0.52-1.67)\end{array}$ & 0.81 & $\begin{array}{c}1.17 \\
(0.69-1.97)\end{array}$ & 0.56 & $\begin{array}{c}1.22 \\
(0.69-2.16)\end{array}$ & 0.50 \\
\hline Severe & $\begin{array}{c}0.75 \\
(0.34-1.68)\end{array}$ & 0.49 & $\begin{array}{c}0.85 \\
(0.37-1.94)\end{array}$ & 0.70 & $\begin{array}{c}0.73 \\
(0.33-1.63)\end{array}$ & 0.44 & $\begin{array}{c}0.68 \\
(0.28-1.65)\end{array}$ & 0.39 \\
\hline
\end{tabular}

*Logistic regression models adjusted for stunting, age (years) and sex of the child, maternal literacy (yes/ no), household caste, ethnicity, iron/zinc supplementation group, and an asset ownership scale (ordinal variable ranging from 0 to 10 from a composite score of 1 if 'yes', 0 if 'no' on ownership of latrines, cattle, goats, carts, bicycles, radios, electricity in home, land, televisions, and presence of servants); ${ }^{* *}$ Logistic regression models adjusted for wasting, age (years) and sex of the child, maternal literacy (yes/no), household caste, ethnicity, iron/zinc supplementation group, and an asset ownership scale (ordinal variable ranging from 0 to 10 from a composite score of 1 if 'yes', 0 if 'no' on ownership of latrines, cattle, goats, carts, bicycles, radios, electricity in home, land, televisions, and presence of servants); §Refer to Table 1 for full questions; $\dagger$ Moderate defined as $<-2 \mathrm{SD}$ and severe defined as $<-3 \mathrm{SD}$; $\neq$ Wasting defined as WHZ $<-2 \mathrm{SD}$, and stunting defined as $\mathrm{HAZ}<-2 \mathrm{SD}$; CI=Confidence interval; $\mathrm{HAZ}=$ Height-for-age $\mathrm{z}$-score; $\mathrm{OR}=$ Odds ratio; $\mathrm{SD}=$ Standard deviation from the mean; TQP=Ten Questions Plus; WHZ=Weight-forheight z-score

stone delay. Severe stunting was also associated with increased adjusted odds of a positive response to Question 7: learning (OR=2.01, 95\% CI 1.273.20). The $\mathrm{p}$ values for likelihood ratio tests for each model were all $<0.0001$. The $p$ values from Hosmer-Lemeshow goodness-of-fit tests for each model were $<0.05$.

\section{DISCUSSION}

Overall, roughly one in four children in our sample screened positive on the TQP. Moderate stunting and severe stunting were associated with parental report of delayed motor milestone attainment for sitting, standing, and walking. Stunting was also 
associated with reports of delayed mental development, such as not learning to do things like other children of the same age. The two most common positive responses were associated with relative motor and cognitive deficits, as perceived by parental report.

The association between positive screening on the TQ and stunting has also been found in South America, Africa, eastern Europe, and Asia (see footnote in Table 4) (2). A validation study of the TQ tool in Pakistan estimated that the screen alone overestimated the prevalence of true child disability by more than $300 \%$ (18). Our TQP screen-positive proportion of $27.0 \%$ is a reasonable estimate of those children who are at an increased risk of disability or developmental delay given the global range of screen-positive proportions (Table 4). Results of another study in Pakistan with both urban and rural children, using the TQ to screen for mental retardation, showed that rural children were at greater risk of mental disability than urban children (19). We found a higher proportion of screen-positive cases in our rural sample than was found in Bangladesh, which included rural and urban areas (20.9\% screen-positive) (Table 4) (4).
We have previously studied a subset $(\mathrm{n}=485)$ of the 1,902 children in Sarlahi, Nepal and found that children with better length-for-age and weight-forlength z-scores were associated with earlier age at walking (20). However, the TQP screen has never been used in this population before the present study was conducted. The present study followed children at a later age than our previous study, after most of them have attained their major motor milestones. Additionally, the TQP can identify multiple disabilities as it screens for many other physical and cognitive disabilities beyond motor milestones.

In our study, males had a higher probability of screening positive $(\mathrm{OR}=1.30)$, similar to that found in Bangladesh $(\mathrm{OR}=1.25)$ and Pakistan $(\mathrm{OR}=1.32)$ $(4,19)$. Our findings of a $10.3 \%$ positive response to the developmental milestone question and a 9.6\% positive response to the learning question are higher than that found in any of the 20 countries evaluated by the UNICEF (Table 4). The differences between our results and those of other countries may be attributable to cultural variations in translation and understanding of the meaning of the questions,

\begin{tabular}{|c|c|c|c|c|c|}
\hline \multirow[b]{2}{*}{ Outcome } & \multicolumn{5}{|c|}{ MICS (4) } \\
\hline & $\begin{array}{c}\text { Low } \\
\text { (country) }\end{array}$ & $\begin{array}{c}\text { High } \\
\text { (country) }\end{array}$ & $\begin{array}{c}\text { Nepal } \\
\text { rural }\end{array}$ & $\begin{array}{c}\text { Bangladesh } \\
\text { urban and } \\
\text { rural (4) }\end{array}$ & $\begin{array}{c}\text { Pakistan } \\
\text { mostly } \\
\text { urban (19) }\end{array}$ \\
\hline \multicolumn{6}{|l|}{ Positive screen (\%) } \\
\hline All children & $\begin{array}{c}2.0 \\
\text { (Uzbekistan) }\end{array}$ & $\begin{array}{c}31.0 \\
(\mathrm{CAR})\end{array}$ & $27.0^{*}$ & 20.9 & 14.7 \\
\hline $\begin{array}{l}\text { In severely- } \\
\text { stunted children }\end{array}$ & $\begin{array}{c}6.1 \\
\text { (Uzbekistan) }\end{array}$ & $\begin{array}{c}55.6 \\
\text { (Belize) }\end{array}$ & $31.2^{*}$ & NA & NA \\
\hline $\begin{array}{l}\text { In severely } \\
\text { underweight children }\end{array}$ & $\begin{array}{c}0.0 \\
\text { (Albania and } \\
\text { Uzbekistan) }\end{array}$ & $\begin{array}{c}100.0 \\
\text { (Montenegro) }\end{array}$ & $24.3^{*}$ & NA & NA \\
\hline Yes $(\%)$ & & & & & (18) \\
\hline Motor milestones & $\begin{array}{c}0.4 \\
\text { (Uzbekistan } \\
\text { and } \\
\text { Montenegro) }\end{array}$ & $\begin{array}{c}8.6 \\
\text { (Belize) }\end{array}$ & 10.3 & 7.4 & 4.5 \\
\hline Fits/seizures & $\begin{array}{c}0.3 \\
\text { (Uzbekistan) }\end{array}$ & $\begin{array}{c}7.1 \\
\text { (Thailand) }\end{array}$ & 1.5 & 1.8 & 2.8 \\
\hline Learning & $\begin{array}{c}0.2 \\
\text { (Montenegro) }\end{array}$ & $\begin{array}{l}11.8 \\
(\mathrm{CAR})\end{array}$ & 9.6 & 5.0 & 0.9 \\
\hline Behavioural problems & NA & NA & 4.5 & $0.6 \dagger$ & NA \\
\hline \multicolumn{6}{|c|}{$\begin{array}{l}\text { *Limited to TQ only (excludes Q11 on behavioural problems); } \dagger \text { After clinical confirmation; \% } \\
\text { of children with positive screen found to be associated with increasing severity of stunting in Belize, } \\
\text { Bosnia and Herzegovina, Cameroon, Ghana, Mauritania, Mongolia, Montenegro, Sao Tome and } \\
\text { Principe, Serbia, Sierra Leone, Suriname, TYFR Macedonia, and Uzbekistan (4); CAR=Central African } \\
\text { Republic; MICS=Multiple indicator cluster survey; NA=Not available; TQ=Ten Questions }\end{array}$} \\
\hline
\end{tabular}


which should be investigated further across South Asia. However, evaluation of the reliability of the TQ in countries with different cultures and levels of socioeconomic development has validated the cross-cultural applicability of the screen (21). Thus, the differences we found may indicate a true higher prevalence of disability relating to motor development and learning problems in this area of rural Nepal than in other southeast Asian countries.

The eleventh question on behavioural problems was more recently added to the questionnaire and has not yet been validated in multiple countries. Where it was evaluated in Bangladesh, there was a $0.6 \%$ prevalence of positive response to this question, which differs from $4.4 \%$ prevalence we found in our sample (Ferdous $S$ et al. Prevalence of childhood disability: the TQP study in Bangladesh. Presented at International Association for the Scientific Study of Intellectual Disabilities Conference, 18 June 2004, Montpellier, France). However, it should be noted that $0.6 \%$ prevalence was observed after clinical confirmation was made on those who initially screened positive; so, it is difficult to compare our findings with clinically-confirmed behavioural problems. This question was only asked about children aged three years and older but the percent responding positively to this question did not vary by age of the child. Since this is a new question, it will likely need validation in other settings.

The underlying biological mechanisms for childhood mental and physical disability are not completely understood and are likely multi-factorial. To date, a causal relationship between stunting and risk of disability could not be established but evidence from a global review supports that malnutrition impairs motor and mental development (4). Additionally, results of studies on children aged less than two years in Zanzibar indicate that nutritional deficiency contributes to cognitive and physical developmental delays $(22,23)$. Chronic malnutrition may contribute to an increased risk of mental developmental delays, or it may be that developmentally-delayed children do not eat as well or receive the same amount of food as those not considered developmentally delayed by their parents (24-26).

Further research needs to assess what roles breastfeeding and micronutrient status play in the biological process of disability development $(4,8)$. In this population, infants were almost universally but rarely exclusively breastfed. Additionally, there are variations in the timing of initiation, which may affect developmental processes later in life (27).

Strengths of our study include that it is population- based with a large sample-size, and the children screened for disability represent a geographicallydistributed sample of Ishwarpur in a rural area of Nepal. Prior parental reports on disability in South Asia have not included the question on behavioural concerns, which were shown to be quite prevalent in this setting. While the association between stunting and positive screening was also found in the results of the MICS 3, anthropometric variables were only available in children aged 2-4 years (8).

\section{Limitations}

Limitations of the study include that the sample was not necessarily representative of the population of Sarlahi or Nepal. It comprised a cohort of survivors of a population-based micronutrient trial. Although we found that the participants were slightly more wasted and may be less socioeconomically well-off compared to those children who did not receive the TQP, we do not believe that this affects the association we found between stunting and screen-positivity. Since we were not able to conduct definitive neuro-developmental evaluations of the children who screened positive, we do not know the sensitivity and specificity of the tool in a rural population like that in Nepal, although its specificity has been demonstrated in similar South Asian populations (5). Since the TQP is based on parental report, it is likely to identify the more severe cases but miss more subtle or mild ones. Additionally, these results may be limited by recall bias, especially for the oldest children in our sample.

\section{Conclusions}

Where past studies have found evidence of the increased risk of physical developmental delays associated with severe stunting, we also identified the risk of cognitive delay. It has been recommended for future work that a more sophisticated disability screen be developed which might include a greater number of questions and scaled categories for responses (28). Our study helps identify the specific disabilities that might be useful to target in developing a more specific screening tool. The contribution of our study is that it demonstrates the feasibility and use of the TQ tool in rural Nepal and confirms the association with nutritional status seen in other populations. We believe that this indicates an unmet need and hope that it will draw attention to the need to screen, definitely diagnose, and intervene to treat these disabilities.

\section{ACKNOWLEDGEMENTS}

The study was conducted by the Department of International Health, Bloomberg School of Public Health, Johns Hopkins University (JHU), Baltimore, 
MD, USA, under grants from the National Institutes of Health, Bethesda, MD (HD 38753), the Bill \& Melinda Gates Foundation, Seattle, Washington, DC (810-2054), and a Cooperative Agreement between the JHU and the Office of Health and Nutrition, US Agency for International Development, Washington, DC (HRN-A-00-97-00015-00).

The authors acknowledge Dr. Naila Khan, Head of the Child Development Centre, Child Development and Neurology Unit, Dhaka Shishu (Children's) Hospital, for her advice and training of the study investigators in the administration of the TQP. The authors have no financial relationships or competing interests relevant to this article to disclose. The corresponding and first authors had full access to all the data in the study and take responsibility for the integrity of the data and the accuracy of the data analysis.

\section{REFERENCES}

1. United Nations. Convention on the rights of persons with disabilities and optional protocol. New York, NY: United Nations, 2006. 37 p. (http://www.un.org/disabilities/documents/convention/convoptprot-e.pdf, accessed on 5 Aug 2009).

2. Grantham-McGregor S, Cheung YB, Cueto S, Glewwe P, Richter L, Strupp B; International Child Development Steering Group. Developmental potential in the first 5 years for children in developing countries. Lancet 2007;369:60-70.

3. Thorburn M, Desai PJ, Paul TJ, Malcolm L, Durkin M, Davidson L. Identification of childhood disability in Jamaica: the Ten Question screen. Int J Rehabil Res 1992;15:115-27.

4. United Nations Children's Fund. Monitoring child disability in developing countries: results from the multiple indicator cluster surveys. New York, NY: United Nations Children's Fund, 2008. 84 p.

5. Durkin MS, Davidson LL, Desai P, Hasan ZM, Khan N, Shrout PE et al. Validity of the Ten Questions screened for childhood disability: results from population-based studies in Bangladesh, Jamaica, and Pakistan. Epidemiology 1994;5:283-9.

6. Berg AL, Papri H, Ferdous S, Khan NZ, Durkin MS. Screening methods for childhood hearing impairment in rural Bangladesh. Int J Pediatr Otorhinolaryngol 2006;70:107-14.

7. Khan NZ, Ferdous S, Islam R, Sultana A, Durkin M, McConachie H. Behaviour problems in young children in rural Bangladesh. J Trop Pediatr 2008;55:17782.

8. Gottlieb CA, Maenner MJ, Cappa C, Durkin MS. Child disability screening, nutrition, and early learn- ing in 18 countries with low and middle incomes: data from the third round of UNICEF's multiple indicator cluster survey (2005-06). Lancet 2009;374:18319.

9. Singhi P, Kumar M, Malhi P, Kumar R. Utility of the WHO Ten Questions screen for disability detection in a rural community the North Indian experience. $J$ Trop Pediatr 2007;53:383-87.

10. Belmont L. Screening for severe mental retardation in developing countries: the international pilot study of severe childhood disability. In: Berg JM, editor. Science and service in mental retardation: proceedings of the Seventh Congress of the International Association for the Scientific Study of Mental Deficiency. London: Methuen Ltd., 1986:389-95.

11. Tielsch JM, Khatry SK, Stoltzfus RJ, Katz J, LeClerq SC, Adhikari R et al. Effect of routine prophylactic supplementation with iron and folic acid on preschool child mortality in southern Nepal: communitybased, cluster-randomised, placebo-controlled trial. Lancet 2006;367:144-52.

12. Tielsch JM, Khatry SK, Stoltzfus RJ, Katz J, LeClerq SC, Adhikari R et al. Effect of daily zinc supplementation on child mortality in southern Nepal: a communitybased, cluster randomized, placebo-controlled trial. Lancet 2007;370:1230-39.

13. Christian P, Stewart CP, LeClerq SC, Wu L, Katz J, West KP, Jr. et al. Antenatal and postnatal iron supplementation and childhood mortality in rural Nepal: a prospective follow-up in a randomized, controlled community trial. Am J Epidemiol 2009;170:1127-36.

14. de Onis M, Garza C, Onyango AW, Martorell R, editors. WHO child growth standards. Acta Paediatrica Supplementum 2006;450:1-101.

15. Siegel EH, Stoltzfus RJ, Khatry SK, Leclerq SC, Katz J, Tielsch JM. Epidemiology of anemia among 4- to 17-month-old children living in south central Nepal. Eur J Clin Nutr 2006;60:228-35.

16. StataCorp. Stata statistical software: release 10. College Station, TX: StataCorp LP, 2007.

17. SAS Institute Inc. SAS 9.2. Cary, NC: SAS Institute Inc., 2002-2008.

18. Durkin MS, Hasan ZM, Hasan KZ. The Ten Questions screen for childhood disabilities: its uses and limitations in Pakistan. JEpidemiol Community Health 1995;49:431-6.

19. Durkin MS, Hasan ZM, Hasan KZ. Prevalence and correlates of mental retardation among children in Karachi, Pakistan. Am J Epidemiol 1998;147:281-8.

20. Siegel EH, Stoltzfus RJ, Kariger PK, Katz J, Khatry SK, LeClerq SC et al. Growth indices, anemia, and diet independently predict motor milestone acquisition of infants in south central Nepal. J Nutr 2005;135:28404. 
21. Durkin MS, Wang W, Shrout PE, Zaman SS, Hasan ZM, Desai P et al. Evaluating a Ten Questions screen for childhood disability: reliability and internal structure in different cultures. J Clin Epidemiol 1995; 48:657-66.

22. Olney DK, Kariger PK, Stoltzfus RJ, Khalfan SS, Ali NS, Tielsch JM et al. Development of nutritionally at-risk young children is predicted by malaria, anemia, and stunting in Pemba, Zanzibar. J Nutr 2009;139:76372.

23. Olney DK, Pollitt E, Kariger PK, Khalfan SS, Ali NS, Tielsch JM et al. Young Zanzibari children with iron deficiency, iron deficiency anemia, stunting, or malaria have lower motor activity scores and spend less time in locomotion. J Nutr 2007;137:2756-62.

24. Yousafzai AK, Filteau S, Wirz S. Feeding difficulties in disabled children leads to malnutrition: experience in an Indian slum. Br J Nutr 2003;90:1097-106.

25. Yousafzai AK, Pagedar S, Wirz S, Filteau S. Beliefs about feeding practices and nutrition for children with disabilities among families in Dharavi Mumbai. Int J Rehabil Res 2003;26:33-41.

26. Mallory BL, Nichols RW, Charlton JI, Marfo K. Traditional and changing views of disability in developing societies: causes, consequences, cautions. Durham, NH: World Rehabilitation Fund, 1993. 105 p. (World Rehabilitation Fund monograph no. 53).

27. Mullany LC, Katz J, Li YM, Khatry SK, LeClerq SC, Darmstadt GL et al. Breast-feeding patterns, time to initiation, and mortality risk among newborns in southern Nepal. J Nutr 2008;138:599-603.

28. Trani JF. Screening children for disability. Lancet 2009:374;1806-7. 